\title{
How Thai EFL Learners Deal With English Regular Past Forms: A Case Study of a Speech Sound Perspective
}

\author{
Kotchawara Yaowaratana ${ }^{1} \&$ Apichai Rungruang ${ }^{1}$ \\ ${ }^{1}$ Department of English, Faculty of Humanities, Naresuan University, Thailand \\ Correspondence: Kotchawara Yaowaratana, Faculty of Humanities, Naresuan University, Tha Pho District, \\ Amphoe Mueang, Phitsanulok, Thailand. Tel: 669-3524-9239. E-mail: kotchawara.y@gmail.com
}

Received: May 1, 2018 Accepted: June 1, 2018 Online Published: June 3, 2018

doi: 10.5539/elt.v11n7p1 URL: http://doi.org/10.5539/elt.v11n7p1

\begin{abstract}
The pronunciation of regular past tense verbs seems to be difficult for most L2 learners, especially in L2 learners whose first language phonological system is different from the English one. It is predicted that Thai EFL students could encounter difficulties perceiving English coda clusters like the '-ed' ending sounds. For this reason, this research investigates the extent to which the first-year and the third-year English major undergraduate students in a public university perceive the English regular past tense verbs. To be precise, this study compares the ability to perceive the regular past tense of the first-year and third-year students. In addition, the strategies they use to perceive the '-ed' ending verbs among the three different allomorphs ([t], [d] and [Id]) are investigated. The data collection was derived from the perception tests of 30 first-year and 30 third-year students and a Pronunciation Learning Strategy (PLS) questionnaire. The perception tests were divided into two subtests: perception test and perception syllable identification test. The PLS questionnaire was employed to find out the strategies they used in English pronunciation learning. The overall results show that the third-year students demonstrated a better performance than the first-year students in both tests $(t=-2.778 ; \mathrm{p}<.01$ in the perception test; $\mathrm{t}=-1.466 ; \mathrm{p}>.05$ in the syllable identification test). However, the syllable identification test's results do not show consistency with Solt et al.'s (2004) model, while the perception test's do. Moreover, the findings from the questionnaire reveal no statistically significant difference between the first and the third-year students in terms of pronunciation learning strategies ( $>$ >.05).
\end{abstract}

Keywords: regular English past forms, perception test, pronunciation learning strategies

\section{Introduction}

In English, the past simple tense is usually used to represent actions or states which occur in the past and which are already finished. Generally, past time references such as yesterday, last month or two years ago are added in past simple sentences to specify the past events. Besides adverbs of time, verbs are used to show past events in English as well. The past simple tense verbs were divided into two groups, regular and irregular verbs. In general, there are fewer irregular verbs than regular in English. The irregular verbs do not form their past tense by adding a suffix '-ed' to the stem, but by other methods such as ablaut, pseudo-inflection, suppletive, and identical forms (Declerck, Reed, \& Cappelle, 2006; Prapobaratanakul \& Pongpairoj, 2016). The regular forms are much simpler and more straightforward than the irregular ones in that only a suffix '-ed' is attached at the end of a word. It is found that the regular past is used more inconsistently than the irregular past (Wolfram, 1985 and Bayley, 1994 as cited in Solt et al., 2004). Celce-Murcia, Brinton, and Goodwin (1996) propose that students whose first language has more restricted final consonant clusters than English frequently pronounce every '-ed' endings as fully syllabic [Id] or [əd] owing to lacking knowledge of past tense marking phonological rules. Bayley (1996) adds that a barrier to perceiving or even producing English regular past may arise from the phonological factors, namely L1 transfer or variable L2 input. In addition, Solt et al. (2004) suggested that the main obstacle to correctly producing the three allomorphs of the '-ed' morpheme is the inability of L2 learners to perceive these allomorphs consistently. In recent years, there has been an increasing interest in the study of the English regular past tense verbs in different aspects, from child language acquisition (Blom \& Paradis, 2013) to adult language acquisition (Birdsong \& Flege, 2001; Solt et al., 2004; Lardiere, 2002; Sriphrom \& Ratitamkul, 2014; Prapobaratanakul \& Pongpairoj, 2016). However, far too little attention has been paid to regular past tense verbs by Thai scholars. The Thai researchers to date have tended to focus on morphological perspectives rather than 
phonetic or phonological aspects. Therefore, this present study was conducted to draw a picture of how EFL Thai learners dealt with sounds in the '-ed' ending verbs in English and what strategies the Thai university students employed when learning English regular past tense verbs.

\subsection{Purposes of the Study}

The aim of this study is to investigate the extent to which the first-year and the third-year undergraduate students at a Thai public university perceive the English regular past tense verbs. In other words, this study compares the ability to perceive the regular past tense of the first-year and third-year students. Furthermore, this study examines the strategies they use to perceive the '-ed' ending verbs among the three different allomorphs $([\mathrm{t}]$, [d] and $[\mathrm{Id}])$.

\subsection{Research Questions}

1). To what extent do the first-year and the third-year students perceive the English regular past tense verbs among the three different allomorphs ([t], [d] and [Id]) of the regular past '-ed' morpheme?

2). What are the strategies that the first-year and the third-year students employ to perceive the three different allomorphs of the regular past '-ed' morpheme?

\subsection{Research Hypotheses}

Hypothesis 1: The third-year students will perceive the regular past tense verbs with a higher rate of accuracy than the first-year students.

Hypothesis 2: The first-year students and the third-year students use different strategies to perceive the three different allomorphs of the regular past tense '-ed' morpheme.

\section{Literature Review}

The review section is divided into three major parts. One is English past forms; another is past tense pronunciation for regular verbs (-ed), and the other is previous research studies.

\subsection{English Past Forms}

In general, English past verbs can be broken down into two major forms (irregular and regular structure). Declerck, Reed and Cappelle (2006) and Prapobaratanakul and Pongpairoj (2016) state that English irregular past tense verbs can be seen in four major forms, namely ablaut, pseudo-inflection, suppletive, and identical forms. Below are those four irregular past forms and related examples.

- Ablaut shows a vowel change in the past tense forms. Some of them are sit-sat, drink-drank, swim-swam, etc. The vowel changes from high to low vowels. Notice that the base and the past forms are still tense vowels.

- Pseudo-inflection refers to a vowel change but it changes from a long vowel (tense vowel) to a short vowel (lax vowel). Some of them are lead-led, meet-met, or leave-left etc.

- Suppletive means verbs that do not show any relationship between the base form and the past form. Some of them are is-was, go-went, etc.

- Identical forms reflect no changes between the base and the past forms. Some of them are set-set, hit-hit, cut-cut, put-put, etc.

What are English regular verb forms? They are those with an '-ed' ending. In other words, the regular forms are very consistent to show the pastness with the suffix '-ed'. Some of them are live-lived, stay-stayed, talk-talked, etc. However, the '-ed' does not need to refer to the verb, but it can refer to an adjective such as a dedicated worker, a committed student, fried chicken, etc. Nonetheless, this study focuses only on the verb forms. To comprehend how regular verbs are pronounced, see the following part.

\subsection{Past Tense Pronunciation for Regular Verbs (-ed)}

Below are three major rules in the past tense pronunciation for regular verbs (Finegan, 2015).

Rule 1: If the verb base ends in a voiceless sound (such as $\mathrm{p}, \mathrm{t}, \mathrm{k}$, s, etc), then the '-ed' ending sound is pronounced as a $[\mathrm{t}]$. No extra syllable is added.

Rule 2: If the verb base ends in a voiced sound (such as b, d, g, z, etc), then the '-ed' ending sound is pronounced as a [d]. Like the first rule, no extra syllable is added.

Rule 3: If the verb base ends in a [t] or [d] sound (such as test, decide, etc), then the '-ed' ending sound is pronounced as [Id] or [əd].

Unlike the first two rules, another extra syllable is added. In terms of phonological rules, Finegan refers to Rule 
1 as an assimilation rule and Rule 3 as a vowel or schwa insertion rule. To see how scholars deal with past verbs in English, the following parts deal with previous studies by non-Thai and Thai researchers regarding regular and irregular verbs in English.

\subsection{Previous Studies}

\subsubsection{English Past Forms}

By and large, the previous studies on English past tense cover from children language acquisition to adult one in different perspectives. Blom and Paradis (2013) investigated whether L2 children with and without L1 delay differed in their acquisition of the English regular and irregular past tense or not. In terms of irregular verbs, the findings reveal that $\mathrm{L} 2$ children with normal development performed better than the other group. In regular verbs, both groups had lower accuracy for [Id] than the other two sounds. Children with L1 delay made fewer errors with [d] than [t]; in contrast, children with L1 normal development performed [d] better than $[\mathrm{t}]$ and were most accurate at using the allomorph [d] among the three allomorphs. Thus, the accessibility hierarchy scales for the delay group and the normal development were $[\mathrm{t}]>[\mathrm{d}]>[\mathrm{Id}]$ and $[\mathrm{d}]>[\mathrm{t}]>[\mathrm{Id}]$, which goes against Solt et al.'s study (2004). However, Solt et al.'s study was conducted with adult L2 learners; it might not be applicable to the child L2 learners. The effects of age of arrival to an English native speaking country is found in the literature of English past forms (Birdsong \& Flege, 2001). Divided into ages of child, adolescence, and adult groups, Korean and Spanish participants took a multiple choice test on past regular/irregular tense. The findings confirm that the earlier, the better. That is, if the participants come to the English speaking country early, they tend to have a high performance in English past forms. In addition, regular past forms reveal a higher score than irregular past forms in three age groups in both Korean and Spanish speakers. However, this study did not pay attention to the three allomorphs of the English past forms. Thus, an analysis in the three past allomorphs does not appear in the study.

Not only have cross-sectional studies been done, but a longitudinal study on English past forms also exists by Lardiere (2002). She examined possible factors affecting past tense marking from a native Chinese native speaker who had been in the US for many years. Like previous studies, the regular past forms were more widely found than the irregular ones. The researcher argues that the participant's mother tongue plays a role here since Chinese does not allow final clusters in its system. As a result, a $[t, d]$ deletion strategy was found. Nonetheless, Lardiere did not mention much about the three past tense forms. Only the two sounds $[t, d]$ are mentioned. She claims that possible factors affecting the past tense marking are the phonological reduction, the role of aspect, the role of discourse foregrounding/backgrounding, and the declarative/procedural model. The most relevant study dealing with speech sounds to the present study is carried out by Solt et al. (2004) to explore production and perception in English regular past forms. The researchers collected data from adult L2 learners of English whose L1 were Russian, Mandarin, Cantonese, Spanish, Turkish, and Arabic. The participants were divided into two groups (low and high proficient groups) and took the perception and production tests. The findings in both groups show that [Id] had higher scores than the other two sounds $([\mathrm{d}, \mathrm{t}])$ because it was the most salient one. In addition, [d] was the most difficult sound for both groups. As a result, Solt et al. proposes a hierarchical scale as: $[\mathrm{Id}]>[\mathrm{t}]>[\mathrm{d}]$. The left sound on the scale is expected to be the easiest one and the right sound the most difficult one to acquire. Since their study deals with speech sound production and perception, the present study employs their scale to measure Thai native speakers, whether this scale is applicable to the Thai EFL learners or not.

Two Thai research studies dealing with English past forms exist in the literature. As a lexical-oriented study, Sriphrom and Ratitamkul (2014) used a cloze test to elicit both regular and irregular past tense forms from university students. Since this study is morphologically-oriented, the target verbs were divided into three lexical aspectual categories, namely state, activity, and telic based on the Aspect Hypothesis. The findings show that the high proficiency group did better than the low proficiency one. In terms of regular and irregular past tense forms, no difference in the use of regular and irregular verbs was found in the high proficiency group, but the other group employed more irregular verbs than regular ones. The other study by Thai researchers related to English past forms was conducted by Prapobaratanakul and Pongpairoj (2016). They had a 40-year-old adult female Thai speaking learner of English take the Grammaticality Judgment Test and then gave an interview to elicit how well the participant could use English past forms in the conversation. Interestingly, the participant did better in irregular past forms than regular past forms in both tests. The authors argued that the influence of the mother tongue played a role here since Thai does not have final clusters in its system. As a result, when the participant pronounced regular forms, the three sounds - [t], [d], and [Id] — were mostly omitted. However, the authors did not mention which one was deleted the most or the least among the three sounds. In sum, the two studies regarding Thai EFL learners--- the former focuses on a written production and the latter on a spoken production---leave some room to expand. That is, the research to date, particularly by the Thai scholars, is morphologically oriented. In addition, the researchers have paid more attention to production performance than 
perception performance.

\subsubsection{Pronunciation Learning Strategies}

The previous research mentioned above revealed some past tense morphological productive difficulties and the effects that caused the morphological perspective problems. In order to enhance these obstacles, various attempts have been made to discover useful solutions to solve the problems or better the L2 learners. These solutions came in the forms of strategies. Recently, Szyszka (2015) investigated Pronunciation Learning Strategies (PLS) which were developed by good English pronunciation speakers, and their beliefs regarding the variables affecting their pronunciation competence. The participants took part in a survey on pronunciation learning strategies and demonstrated their opinions on several aspects affecting the L2 pronunciation learning process. The findings revealed that the $\mathrm{L} 2$ pronunciation acquisition is considerably related to phonological competence, meta-competence, and awareness-raising efforts. Staying in an English speaking environment is one of the major impacts helping them improving their L2 pronunciation. In addition, experience from out-of-class experiences plays more significant role in L2 pronunciation than in-class experience. Unlike Szyszka (2015) who focused on pronunciation learning strategies from advanced learners, Rokoszewska (2012) was interested in pronunciation from low proficiency learners. He found that students preferred indirect strategies to direct strategies on their perception and production of English monophthongs (pure vowels) and diphthongs. They mostly used metacognitive strategies referring to planning for a language task, paying attention to pronunciation in general, and self-monitoring to improve their pronunciation learning. In the case of direct strategies, cognitive strategies, namely reading aloud, talking to themselves in a target language, and checking the pronunciation of new words in dictionaries, are the most common strategies they employed. In other words, the low proficiency students preferred to be dependent on formal classroom practice rather than naturalistic practice (outside classroom). From both studies, it is found that good pronunciation learners and low proficiency learners mostly employed different strategies to enhance their English pronunciation learning. To confirm whether the findings are applicable to the Thai ELF learners, the present study also attempts to explore the pronunciation learning strategies from both groups.

\section{Theoretical Framework}

\subsection{The Markedness Theory}

Since last century, the concept of markedness has been studied and applied in various fields of knowledge. In terms of linguistic perspectives, markedness has been extensively taken into account and has been applied in various levels of linguistic analysis such as phonology, vocabulary, syntax, and discourse. According to Saville-Troike (2006), the notion of markedness is concerned with "whether any specific feature of a language is marked or unmarked" (p. 55). A feature of a language is considered to be "unmarked" if it occurs more frequently, it is more normal or expected, or its structure is less complex than a contrasting element in the same category. In terms of second language phonological acquisition, the concept of the Markedness Differential Hypothesis (MDH) by Eckman (1977) indicating the markedness relation cross-linguistically has been applied to current research (Celce-Murcia, Brinton, \& Goodwin, 1996; Jin, 2008). The Markedness Differential Hypothesis can be used as a measure of relative difficulty in second language phonological acquisition. Eckman (1977) suggests that the extent of difficulty which a language learner will have can be predicted as follows:

(a) Those areas of the target language which differ from the native language and are more marked that the native language will be difficult,

(b) The relative degree of difficulty of the areas of difference of target language which are more marked that the native language will correspond to the relative degree of markedness;

(c) Those areas of the target language which are different from the native language, but are not more marked than the native language, will not be difficult.

To exemplify the notion of markedness in terms of English pronunciation, one of the English phonology research studies illustrates an interesting markedness scale in terms of perception and production of the English regular past form by non-native adult learners. To be more precise, Solt et al. (2004) investigated the ability to correctly perceive and produce the English regular past tense morpheme '-ed'. The overall results show that the ability to perceive and produce the morpheme '-ed' of the non-native adult learners including Mandarin, Cantonese, Russian, Spanish, Turkish, Arabic, Ukrainian and French Creole can be shown as this hierarchical scale: [Id] > $[\mathrm{t}]>[\mathrm{d}]$. The participants in both groups (low proficiency learners and high proficiency learners) accurately perceived the syllabic allomorph [Id] which is the most unmarked feature on the scale. Nevertheless, one of the results of their study reveals a noticeable markedness of the non-syllabic allomorphs: the voiced stop [d] and the 
voiceless stop [t]. The participants in the high proficiency group performed more accurately on the perception of $[t]$ than $[d]$. Hence, the researchers proposed that "this pattern may relate to the unmarked nature of the voiceless stop [t] compared to the more marked nature of its voiced counterpart [d]" (Solt et al., 2004, p. 561). The results of Solt et al.'s study shows that the non-native learners of English had difficulties in perceiving the English regular past tense allomorphs $[t]$ and $[\mathrm{d}]$ due to the markedness in phonology between languages. In other words, the unmarked feature, the English regular past tense allomorph [Id], is considered to be easier to perceive and produce than the more marked feathers, the allomorphs [t] and [d]. For one important reason, [Id] is more salient than the other two. In this study, the researchers employed Solt et al.'s study to predict that both groups would follow Solt et al.'s markedness hierarchical scale, particularly the high proficiency group. That is, both would have the highest score in [Id] and lowest scores in [d].

In the light of Markedness Theory, it was predicted that the third-year students (high proficiency group) would get higher scores in every regular past tense verbs allomorphs than the first-year students (low proficiency group) since the high proficiency group have studied more English courses than the low proficiency group; especially the former group already took, "English Phonetics and Phonology" course to help them understand how to pronounce English regular past tense, but the latter had not yet taken the course when this study was being conducted.

\subsection{Language and Pronunciation Learning Strategies}

Oxford (1990 cited in Zare, 2012) provides the most applicable definitions of language learning strategies. She states that language learning strategies are "specific actions taken by the learner to make learning easier, faster, more enjoyable, more self-directed, more effective, and more transferable to new situations" (p. 164).

Oxford (1990) has divided language learning strategies into two main categories, direct and indirect strategies, which can be classified into six classes. Direct strategies consist of memory strategies dealing with the process of storing new information and retrieving them when needed, cognitive strategies leading to the process of handling the target language in conscious ways, and compensation strategies enhance learners to use the language both in speaking and writing although learners still have knowledge gaps.

Table 1. The subclasses of memory, cognitive and compensation strategies

\begin{tabular}{|c|c|c|}
\hline \multicolumn{3}{|l|}{ Direct strategies } \\
\hline Memory Strategies & Cognitive Strategies & Compensation Strategies \\
\hline Creating mental linkages & Practicing & Guessing intelligently \\
\hline $\begin{array}{l}\text { Applying images and } \\
\text { sounds }\end{array}$ & Receiving and sending messages & $\begin{array}{l}\text { Overcoming limitations in -speaking and } \\
\text { writing }\end{array}$ \\
\hline Reviewing well & Analyzing and reasoning & \\
\hline Employing actions & $\begin{array}{l}\text { Creating a structure for input and } \\
\text { output }\end{array}$ & \\
\hline
\end{tabular}

In addition, Oxford (1990) explains that the indirect strategies are the strategies that help learners learn the target language indirectly by employing different strategies. She proposes three main strategies, namely metacognitive, affective, and social strategies. Metacognitive strategies lead learners to control their own cognition. Affective strategies support learners to manage their emotions, motivation, and attitudes about their learning. Social strategies offer learners to have the opportunities to learn the target language by interacting with other people. 
Table 2. The subclasses of metacognitive, affective and social strategies

\begin{tabular}{lll}
\hline $\begin{array}{l}\text { Indirect Strategies } \\
\text { Metacognitive Strategies }\end{array}$ & Affective Strategies & Social Strategies \\
\hline $\begin{array}{l}\text { over-viewing and linking with material } \\
\text { already known }\end{array}$ & $\begin{array}{l}\text { lowering anxiety } \\
\text { paying attention }\end{array}$ & $\begin{array}{l}\text { encouraging oneself } \\
\text { empathizing with others }\end{array}$ \\
$\begin{array}{l}\text { delaying speech production } \\
\text { organizing }\end{array}$ & & \\
setting goals and objectives & & \\
planning for a language task & & \\
looking for practice opportunities & & \\
self-monitoring and self-evaluating & & \\
\hline
\end{tabular}

According to a definition provided by Pawlak (2010 cited in Szyszka, 2015), pronunciation learning strategies are "deliberate actions and thoughts that are consciously employed, often in a logical sequence, for learning and gaining greater control over the use of various aspects of pronunciation" (p. 96). The definition of pronunciation learning is also defined as "specific actions taken by the learner to make learning pronunciation easier, faster, more enjoyable, more self-directed, more effective and more transferable to new situations" (Oxford, 1990 cited in Rokoszewska, 2012, p. 392). Similarly to language learning strategies, "good pronunciation users" (GPU) have attracted the interest of several researchers in order to investigate the types of pronunciation learning strategies they deployed. To identify a good pronunciation user, Szyszka (2015) follows the notion of Brown (2008) that there are "three variables associated with good language learners in pronunciation learning: motivation, aptitude, and opportunity" (p. 95). Moyer (2004 cited in Szyszka, 2015) identifies conscious effort, intentionality, and planning toward a goal as the basic elements of motivation to affect the acquisition of target language pronunciation. Additionally, Carroll (1960 cited in Rubin, 1975) proposes that language aptitude is a comparatively invariant personal characteristic that is not easy to modify by means of learning. Furthermore, learners should find the opportunities to practice their foreign language both within and outside the classroom. As investigated by Szyszka's (2015), GPU believed that learning English pronunciation outside the classroom had a better influence than inside the classroom. Moreover, to mostly perceive foreign language, GPU used various ways such as listening to multimedia, talking out loud or silently to themselves in English, and imitating native speakers.

Together with learning strategies, the three variables consistently proceed while a learner decides to learn a language. To succeed in pronunciation learning, learners consciously realize which strategies are the most appropriate for them and employ that strategy throughout their learning process. However, one learner may employ more than one strategy to make his/her learning process run smoothly and to get prosperous results. Hence, the present study focuses on the strategies used by Thai EFL students who are first-year and third-year English major undergraduate students from a public university.

\section{Methodology}

\subsection{Participants}

The participants in this study were divided into two major groups. Both groups were undergraduate students from a public university. The first group was comprised of thirty first-year students whose age range was between 18-19 years old. Most of them had studied English for fourteen years, and they had taken only four English courses since they started their undergraduate degree program. The second group was thirty third-year English major students with ages of 21-22. They had learned English in class for seventeen years as well as had taken nineteen English courses in the university. Unlike the first group, the third-year students did take a required course "English Phonetics and Phonology" of which contents explain English sounds and their systems including the topics of vowels, consonants, organs of speech, minimal pairs, phonemes, allophones and rules of sound. Thus, the third-year students who had already taken the English Phonetics and Phonology were considered to have a higher proficiency level than the first-year students who had never taken the Phonetics and Phonology course. 


\subsection{Research Instruments}

To examine the extent to which the first-year and the third-year students perceived the English regular past tense verbs as well as to compare the ability of them in perceiving the regular past tense allomorphs, a quantitative method was employed for gathering data. Two research instruments were used in this step; a perception test and a syllable identification test were employed for answering the first research question. Besides, to answer the second research question, a questionnaire was distributed to elicit the strategies that both groups employ to perceive the three different allomorphs of the regular past '-ed' morpheme. Below are details about the two research instruments.

\subsubsection{Perception Test}

The perception test was employed to investigate the proficiency level of the first-year and the third-year English major students of perceiving the regular past tense verbs. The test consisted of thirty-five words without contexts. Five tricky words (test items 1-5 were used to relieve their excitement so they were not counted when the test was done); fifteen regular past form lexical words were selected from an English book of a secondary school in Thailand (Upstream 6); finally fifteen pseudo words (a series of letters that can be pronounceable but they do not exist in the language). Therefore, only thirty items were counted in this test. The chosen regular past tense verbs in this test were equally divided into three groups as follows.

1). The regular past tense verbs ending with voiceless consonant, the sound of a certain consonant which is produced without the vibration of vocal folds such as /p/, /k/, /f/, /s/, / / /, / f/ and /e/ (Carr, 2012, p. 2)

2). The regular past tense verbs ending with voiced consonant or vowel, the sound of a certain consonant which is produced with the vibration of vocal folds such as $/ \mathrm{b} /, / \mathrm{v} /, / \mathrm{g} /, / \mathrm{z} /, / \mathrm{j} /, / \mathrm{d} /, / \mathrm{l} /, / \mathrm{m} /, / \mathrm{n} /$ and $/ \mathrm{r} /(\mathrm{Carr}, 2012, \mathrm{p} .2)$

3). The regular past tense verbs ending with $/ t /$ and $/ d /$

To form the perception test, a male American native speaker pronounced each chosen word twice. The pause between the first and second readings was three seconds. All audio sounds were recorded and saved on a laptop computer. Then, the researcher made an appointment with each group of students to take the test in a classroom. The students were asked to listen carefully to each word, then circled the best answer (a, b, c, and d). The test took approximately twenty-five minutes to complete. The answers of the test were scored by the researchers. A correct item was counted 1 point and an incorrect item was counted 0 points.

\subsubsection{Perception Syllable Identification Test}

The syllable number identification test was designed to attest the results of the perception test and to investigate the consistency of the perception's results with the research question one. All words used in this test were the same as in the perception test. Thus the major focus was also on fifteen regular past form lexical words and fifteen pseudo words. In the syllable identification test, it started immediately after the participants finished the perception test. The students were asked to listen carefully and identify how many syllables they heard for each word. After listening to individual tokens, they had to write down the number of syllables on the test paper sheet. The researcher used the same audio sounds as those in the perception test. It took twenty-five minutes to complete the test. In this test, the researchers checked all the answers by marking 1 point for a correct answer and 0 points for an incorrect answer.

\subsubsection{Pronunciation Learning Strategies Questionnaire}

In this study, the Pronunciation Learning Strategy (PLS) questionnaire was employed to find out what strategies that the first-year and the third-year students used to perceive and identify the three different allomorphs of the regular past tense morpheme. Replicating the PLS questionnaire in Rokoszewska's study (2012) on the base of Oxford's (1990) classifications, the researchers divided the questionnaire questions into two sections. The first section referred to general information about the participants including gender, age, English language study experience, and the second section provided the information about participants' strategies in sound perception. In section two, according to Oxford's (1990) Language Learning and Pronunciation Learning Strategies, the questions were classified into six parts: memory strategies (items 1-7), cognitive strategies (8-17), compensation Strategies (18-21), metacognitive strategies (22-26), affective strategies (27-31), and social strategies (32-35). The participants were informed to rate how frequently they used them on a 5-point Likert scale, from 1- never to 5 always.

\subsection{Research Validity and Reliability}

In this study, the IOC (Index of Item-Objective Congruence) was used to testify all tests and the questionnaire questions in order to ensure that all tokens and questions fit the objective of the study. All thirty counted words 
used in the tests were sent to three experts in English phonetics and linguistics to check whether they were appropriate for examining the proficiency level to perceive the regular past tense verbs by first-year and third-year English major students. Likewise, the questionnaire questions were also checked by the three experts to justify and adjust each question to suit with its category and appropriate for eliciting the information about language learning and pronunciation learning strategies of the learners. After checking by the three experts, the researcher made a few changes in terms of words used in the tests and some contents in questionnaire questions. With this, content validity was established.

Moreover, a pilot study was also conducted to assure and check the validity and reliability of the tests and the questionnaire. The pilot study was processed with ten first-year and ten third-year English major students from another public university. The results of the pilot study were used to improve the research instruments and gave a good chance to the researchers to see some difficulties when doing the data gathering. To be more precise, while running the pilot study, the researchers found some problems regarding time limitation and the sound environment around the testing room. Due to the limitation of the testing room, the audio sounds were not of a good quality. The students could not clearly listen to the recorded sounds. Thus, the researchers managed the proper scheduled time and prepared a better soundproof room for the tests when carrying out the present study.

\subsection{Procedure}

The present study was carried out in the first semester of the academic year 2017. As mentioned earlier, the researchers scheduled the participants in both groups to take the perception test and syllable identification test. In each group, all thirty participants sat in the same room and took the test at the same time. The participants were asked to listen carefully to the audio sounds. Each item was pronounced twice. The pause between the first and second readings was 2-3 seconds. The participants chose the best answer from the four choices (a, b, c, and d). The test took approximately twenty-five minutes to complete. Shortly after the participants completed the perception test, the syllable identification test was handed out. The participants were asked to listen to the same audio sounds as in the perception test. What they had to do was to write the number of the syllables of a word they heard on the paper sheet. It also took them another twenty-five minutes to complete the test. Finally, the questionnaire was distributed to the participants. They were requested to fill out the questionnaire relating to their pronunciation learning strategies. The questionnaire took about fifteen minutes. Below is a flowchart of the data collection process.

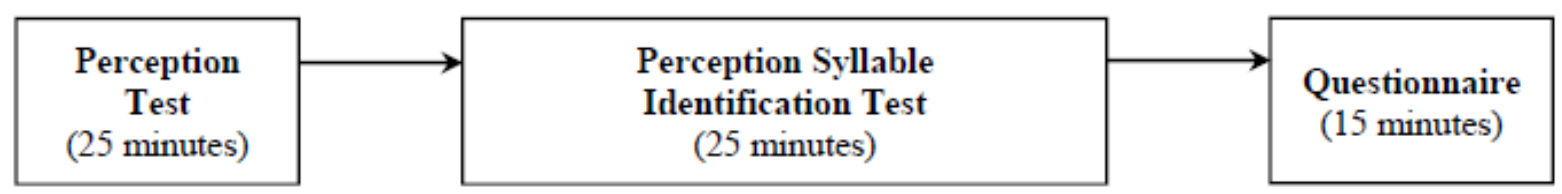

Figure 1. Data collection process

\subsection{Data Analysis}

The collected data from the perception test, the syllable identification test, and the questionnaire were checked by the researchers. Each correct answer would be marked 1 point, and an incorrect answer would be counted 0 points. Items without answers would be considered 0 points. The correct answers of the tests were collected by classifying them into three groups according to three allomorphs of the regular past tense ([t], [d] and [Id]). The data of the 1st and 3rd-year students were computed by SPSS program. The analyzed data were scaled from high to low frequency (e.g., [Id] $>[t]>[d]$ ). The scale respectively showed the extent to which the participants perceived the three allomorphs. The questionnaire's results showing the frequency in percentages demonstrated the most and the least strategies which the participants of the two groups usually use in their pronunciation learning strategies.

\section{Results}

The research findings answer two major research questions with statistical evidence.

First research question: To what extent do the first-year and the third-year students perceive the English regular past tense verbs among the three different allomorphs ([t], $[d]$ and $[\mathrm{Id}])$ of the regular past '-ed' morpheme? 


\subsection{The Results of the Perception Test}

Table 3. Mean scores and standard deviation of both groups in the perception test (total score $=30$ )

\begin{tabular}{llllll}
\hline Group & $\mathrm{N}$ & Mean & $\mathrm{SD}$ & $\mathrm{t}$ & Sig. \\
\hline first-year students & 30 & $18.53(61.77 \%)$ & 1.196 & -2.778 & .008 \\
third-year students & 30 & $19.63(78.57 \%)$ & 1.810 & & \\
\hline
\end{tabular}

According to Table 3, the results of an independent t-test show a significant difference between two groups (first and third-year students) at an alpha level of $0.01(\mathrm{t}=-2.778 ; \mathrm{p}<.01)$. To distinctly understand the differences of perception performances in three allomorphs of both groups, Figure 2 is presented as follows.

\section{Perception Test}

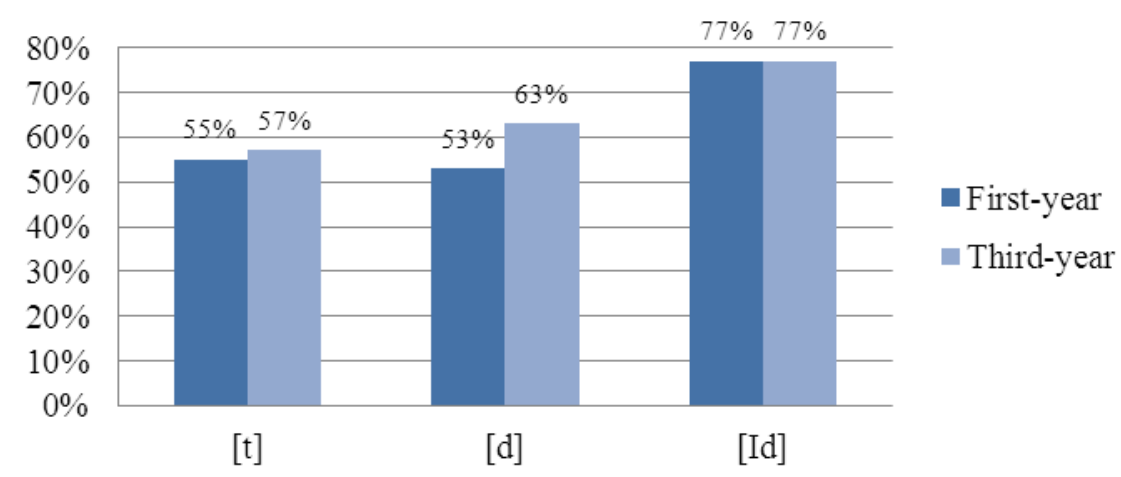

Figure 2. Perception Test Results by allomorph among first and third-year students \% correct

Figure 2 presents the results of the perception test of the first-year and the third-year students, showing the percentage of correct responses in each allomorph ([t], [d], and [Id]). As seen here, both first-year and third-year students performed at ceiling on [Id] (77\%). Additionally, the first-year students had higher scores in [t] (55\%) than [d] (53\%) while the third-year students revealed higher scores in [d] (63\%) than [t] (57\%).

\subsection{The Results of the Perception Syllable Identification Test}

Table 4. Mean scores and standard deviation of both groups in perception syllable identification test

\begin{tabular}{llllll}
\hline Group & $\mathrm{N}$ & Mean & $\mathrm{SD}$ & $\mathrm{t}$ & $\mathrm{Sig}$. \\
\hline first-year students & 30 & $23.57(65.43 \%)$ & 2.661 & -1.466 & .148 \\
third-year students & 30 & $24.77(82.57 \%)$ & 3.607 & & \\
\hline
\end{tabular}

As the statistical data show in Table 4, there is no statistical significance at an alpha level of 0.05 between the first and the third-year students $(t=-1.466 ; \mathrm{p}>.05)$. 


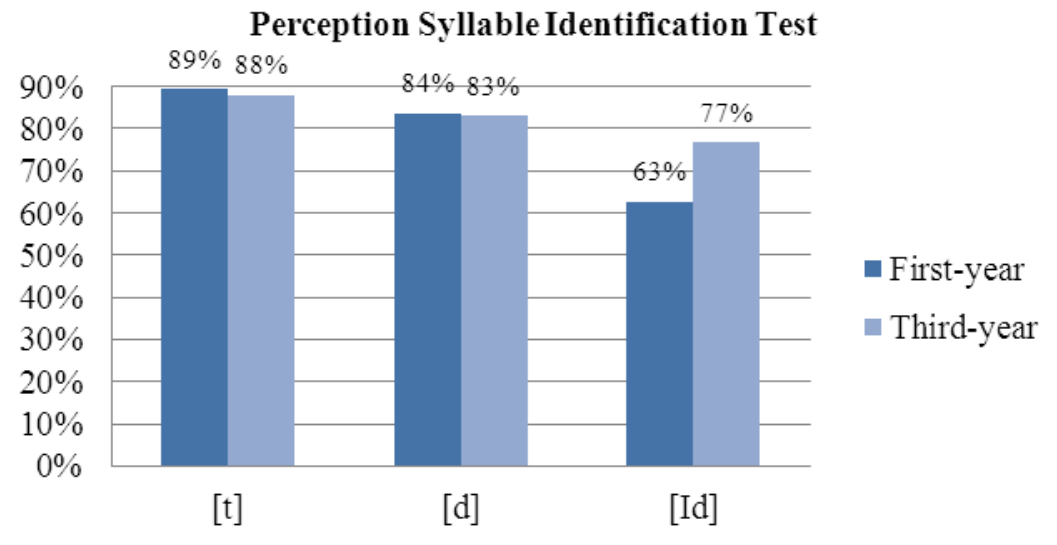

Figure 3. Perception syllable identification test results by allomorph among first and third-year students \% correct

Figure 3 displays the results of the perception syllable identification test among the first-year and the third-year students by showing the percentage scores of the three allomorphs of the regular past tense morpheme. As we can see here, students in both groups had the highest score in [t] $(89 \%$ and $88 \%)$ in perception syllable identification test, then [d] (84\% and $83 \%)$ and [Id] (63\% and $77 \%)$ respectively.

5.3 The Results of Overall Perception Tests

Mean Score \% correct of Orerall Tests

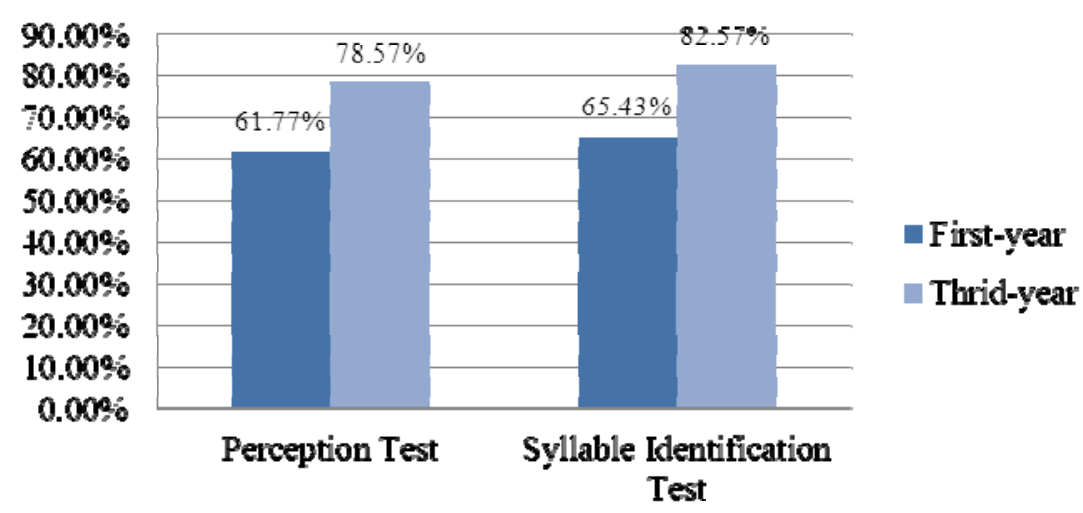

Figure 4. Overall perception tests' results among first and third-year students \% correct

Figure 4 reveals the overall ability to perceive the regular past tense of the first-year and third-year students, presented in mean percentages. According to Figure 4, the mean percentages of the overall ability to perceive the '-ed' ending sounds of the third-year students $(78.57 \%)$ was higher than the first-year students $(61.77 \%)$. Furthermore, the third-year students also had higher scores $(82.57 \%)$ than the first-year students $(65.43 \%)$ in terms of syllable identification.

Second research question: What are the strategies that the first-year and the third-year students employ to perceive the three different allomorphs of the regular past '-ed' morpheme? 


\subsection{The Results of PLS Questionnaire}

Table 5. Mean scores and standard deviation of both groups in the questionnaire

\begin{tabular}{llllll}
\hline Group & $\mathrm{N}$ & Mean & $\mathrm{SD}$ & $\mathrm{t}$ & $\mathrm{Sig}$. \\
\hline first-year students & 35 & 3.3857 & .52582 & .245 & .807 \\
third-year students & 35 & 3.3551 & .51719 & & \\
\hline
\end{tabular}

Table 5 shows that there is no statistical significance at an alpha level of $0.05(t=.245 ; \mathrm{p}>.05)$.

\section{Direct and Indirect Strategies \\ Used by First and Third-year Students}

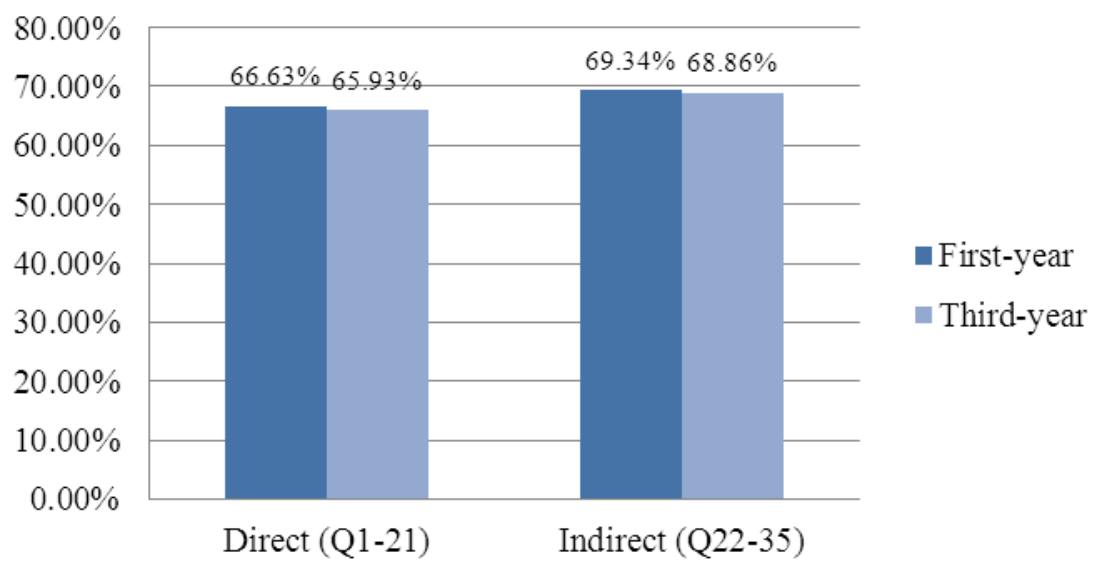

Figure 5 . The mean $\%$ of direct and indirect strategies used by the first-year and the third-year students

The findings presented in Figure 5 show that both first-year and third-year students made a greater use of indirect strategies than direct strategies. More specifically, they used direct strategies at the level of $66.63 \%$ and $65.93 \%$, whereas indirect strategies at the level of $69.34 \%$ and $68.86 \%$, respectively, were used.

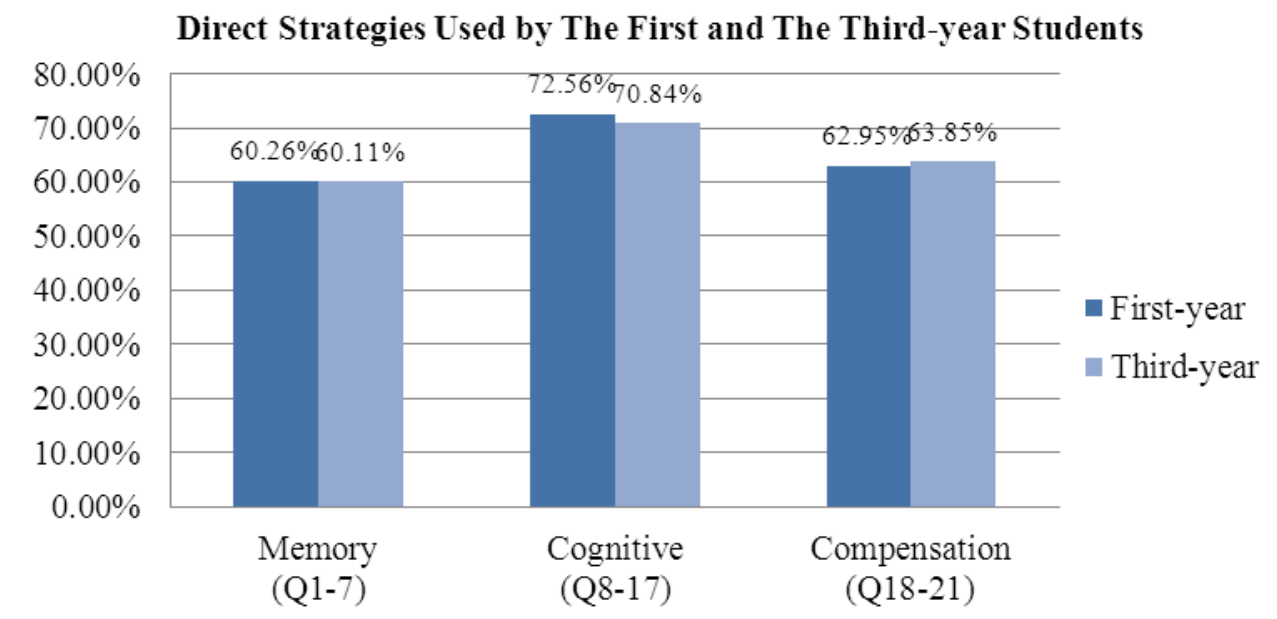

Figure 6 . The mean $\%$ of direct strategies used by the first-year and the third-year students

As the results show in Figure 6 cognitive strategies were mostly used by the first and the third-year students 
(72.56\% and 70.84\%, respectively) when compared to the other two strategies in the same categories (direct strategies). The students used memory and compensation strategies at a similar level. That is, the response rates in memory strategies were $60.26 \%$ and $60.11 \%$ and those in compensation strategies were $62.95 \%$ and $63.85 \%$, respectively.

\section{Indirect Strategies Used by The First-year and The Third-year Students}

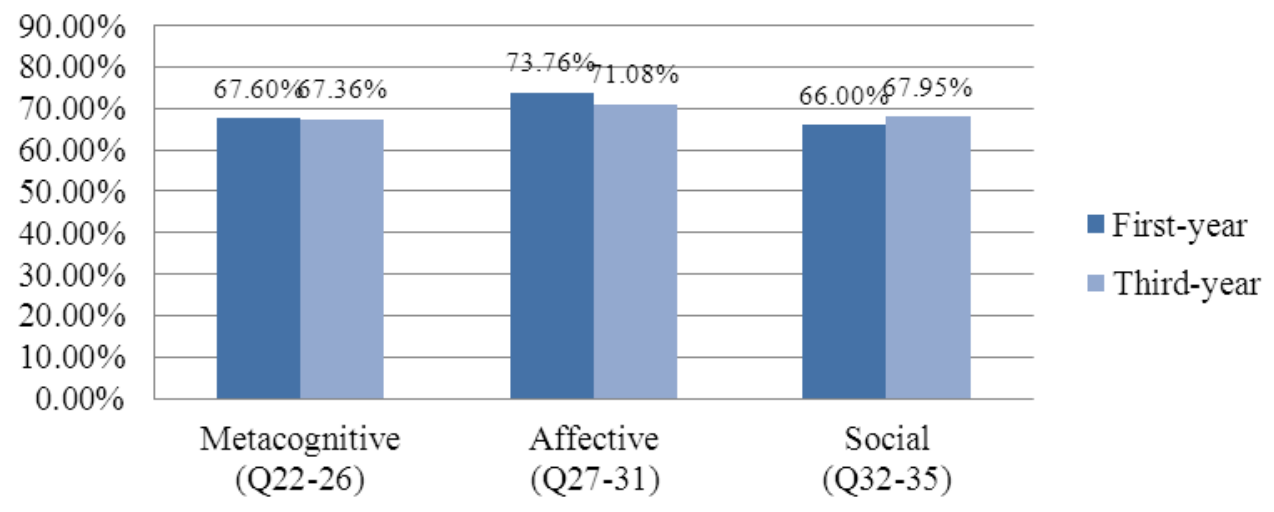

Figure 7. The mean $\%$ of indirect strategies used by the first-year and the third-year students

In Figure 7 as far as indirect PLS are concerned, both groups made the greatest use of affective strategies of all (73.76\% and $71.08 \%$, respectively). Whereas the first and the third-year students used metacognitive strategies at a nearly similar level $(67.60 \%$ and $67.36 \%$, respectively), the social strategies were considered to be used at a higher rate among the third-year students $(67.95 \%)$ than the first-year students $(66 \%)$.

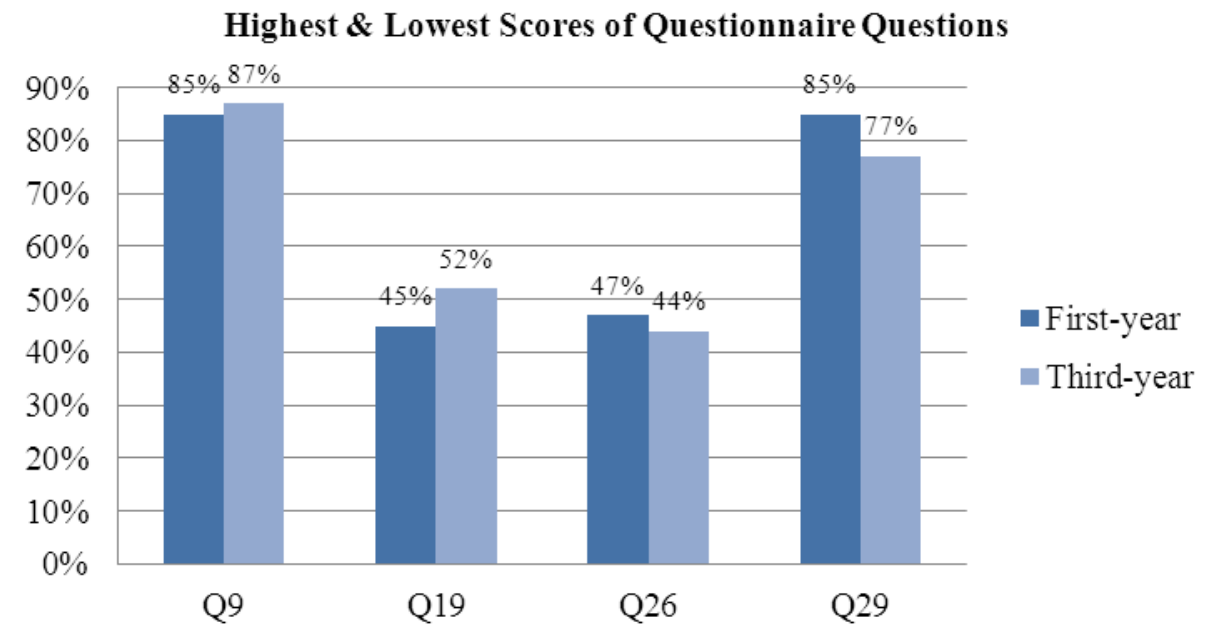

Figure 8. The highest and lowest scores of questionnaire questions by first and third-year students

According to the data appearing in Figure 8, the strategies number 9 and 29 in the questionnaire were rated as the highest score $(85 \%)$ of all by the first-year students while they rated the strategy number 19 as the lowest score $(45 \%)$. Similarly, the strategy number 9 was also rated as the highest score $(87 \%)$ by the third-year students whereas the strategy number 26 was rated as the lowest score $(44 \%)$. Here are the details of the most and the least questionnaire questions rated by both groups;

Q9: I listen to a song or watch any kinds of entertainment in English via the radio, TV or the Internet. 
Q19: If I do not know how to pronounce an "-ed" ending verb, I will avoid using it.

Q26: I evaluate my progress in pronunciation by recording myself and comparing my pronunciation to the pronunciation of native speakers.

Q29: I encourage myself to work on pronunciation even when I think that something is too difficult for me or when I do not feel like learning.

\section{Discussion}

\subsection{Perception}

This present study investigates how well the Thai EFL learners perceive the English regular past tense verbs, and examines the strategies they use for perceiving the '-ed' ending verbs among the three different allomorphs ([t], [d] and [Id]). As predicted in the first hypothesis, the third-year students were able to perceive the regular past tense verbs with a higher rate of accuracy than the first-year students. The analysis of an independent t-test revealed that the third-year students performed significantly better than the first-year students in their perception of the regular past tense morpheme $(\mathrm{p}<.01)$, indicating that experiences of studying English play a major role here.

To answer the first research question, as the results show above, the first-year students can perceive the '-ed' ending sounds as the predicted scale of accessibility: [Id] $>[t]>[d]$. However, allomorph [d] was marked as the second higher score by the third-year students; therefore, the scale of accessibility from the third-year students is: $[\mathrm{Id}]>[\mathrm{d}]>[\mathrm{t}]$. The findings are consistent to the results of Solt et al.'s study in the sense that both first-year and third-year students are able to perceive the syllabic allomorph [Id] accurately better than the non-syllabic allomorphs $[\mathrm{t}]$ and $[\mathrm{d}]$. However, the third-year students' accessibility hierarchy scale does not fit the theoretical framework in that they perceived the voiced [d] better than the voiceless [t]. Now let's consider Table 6.

Table 6. Perception test results showing words in groups of high and low scores

\begin{tabular}{lllllllll}
\hline & High scores & & \multicolumn{3}{c}{ Low scores } \\
& 1 st & & 3rd & & 1st & 3rd & \\
\hline \multirow{2}{*}{ t] $]$} & laughed & runched & runched & laughed & taughed & finished & taughed & finished \\
& 29 & 28 & 30 & 27 & 7 & 6 & 5 & 5 \\
& linged & changed & changed & linged & skumed & ried & moved & ried \\
[d] & 28 & 25 & 29 & 27 & 6 & 6 & 11 & 3 \\
& transmitted & anded & transmitted & anded & debted & plented & indeeded & plented \\
[Id] & 30 & 29 & 29 & 29 & 14 & 8 & 21 & 0 \\
\hline
\end{tabular}

Note. that the numbers under the tokens refer to the total scores from in each $(\mathrm{N}=30)$.

Based on the Markedness Theory, Thai students were supposed to have a higher performance in the syllabic allomorph [Id] since it is the most salient sound when compared to the other two sounds. Hence, the regular past tense verbs ending with the syllabic allomorph [Id] were expected to be easy for Thai students to perceive. As a result, participants in both groups equally perceived the allomorph [Id] with the highest average score at $77 \%$ (Figure 2). Additionally, as shown in Table 6, both groups had the highest scores in the same tokens (transmitted [30/29]), or even if it was a pseudo word (anded [29/29]) which was supposed to be unfamiliar to them. Surprisingly, the term "plented" having the syllabic allomorph [Id] was on the list of lowest scores in both groups. Worse, no single third-year student could identify this term correctly; nonetheless, only eight out of thirty first-year students could identify it. This word seems problematic in both groups, specifically the third year one.

In terms of the non-syllabic allomorphs [t] and [d] when the tokens were grouped into high and low scores; the results revealed that both groups had high and low marks in the same tokens. Interestingly, the third-year group did poorer than the first year one in the term "finished" and "ried". To be more precise, only three third-year students could identify the term "ried", but six first-year students correctly identified it. Five third-year students correctly perceived the term "finished"; six first-year students could do it. Let's consider whether their performance is consistent or not when they took the perception syllable identification test. 
Table 7. Perception syllable identification test results showing words in groups of high and low scores

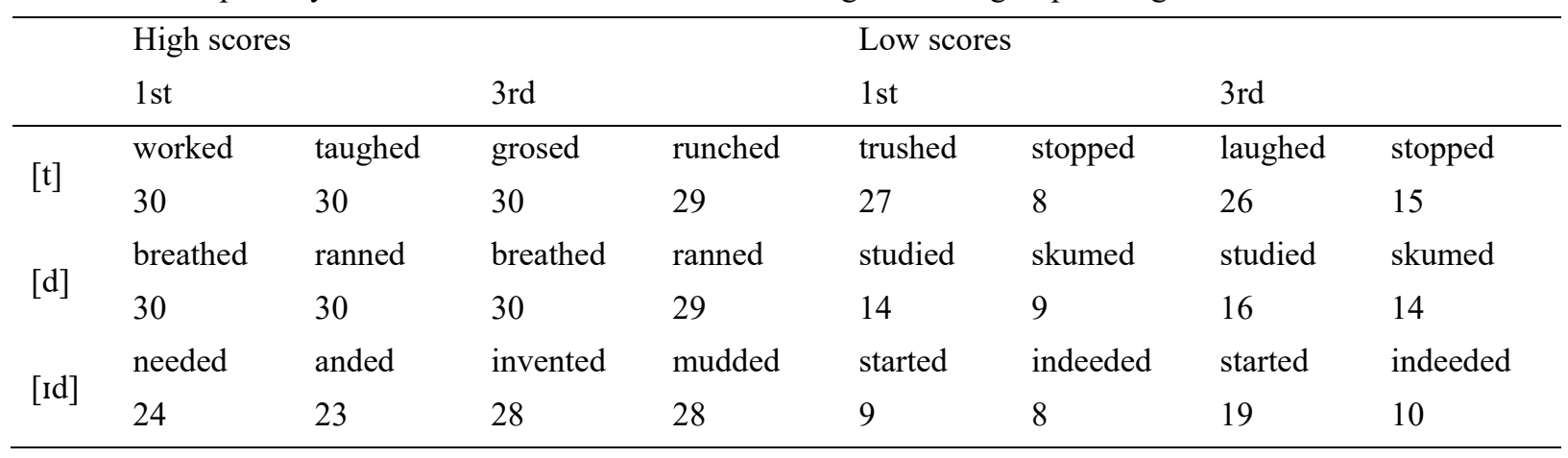

Table 7 shows that the results of the perception syllable identification test are completely different from the perception test's results. Both first-year and third-year students achieved the highest score in the non-syllabic allomorph [t] then [d] which are considered to be the marked form of the '-ed' ending verbs' pronunciation by Thai students, while the syllabic allomorph [Id] had the lowest score. Thus, the sequence of the three allomorphs of the regular past tense morpheme of which both groups could perceive the syllable of each word can be scaled as: $[\mathrm{t}]>[\mathrm{d}]>$ [Id]. Unlike Solt et al.'s (2004) result, the syllabic allomorph [Id], which is assumed to be the unmarked feature for Thai EFL students, shows low scores, especially in low proficiency group (63\%) (as shown in Figure 3). The term "started", which was assumed to be a frequent word for both groups, was on the list of lowest scores.

Interestingly, even though the non-syllabic allomorph [d] is supposed to be the most difficult sound to perceive for L2 learners according to Solt et al.'s (2004) study, in the non-syllabic allomorph [d], both groups did completely well in the same tokens in high scores group (breathed [30/30] and ranned [30/29]), and also the same tokens show on the list of lowest scores (studied [14/16] and skumed [9/14]) in both groups. In the square brackets, the first numbers refer to the first-year students' scores and the second numbers are the third-year students' scores. Since the researchers did not test participants' phonological knowledge of past tense morpheme before conducting the study. Therefore, the results that both groups scored better in non-syllabic allomorphs ([t] [d]) than the syllabic allomorph [Id] may illustrate that both groups did not completely know the phonological rules of past tense morphemes.

Comparing overall performances between the perception test and the syllable identification test, both groups performed better on the syllable identification test $65.43 \%$ in the low proficiency group and $82.57 \%$ in the high proficiency group). This may be due to the design of the tests and the lack of the '-ed' ending phonological rules. Although the researcher used the same audio sounds in both tests, the syllable identification and the perception test employed different answer sheets. That is, when the participants took the syllable identification test, all tokens did not appear on the paper. There were blanks provided for each item. See test samples in the appendix. The participants had to carefully concentrate only on the pronunciation of each word to write down the number of syllables with the result that the overall performances of both groups were rather high. On the other hand, the perception test was a multiple choice test; there were four choices in each item. Thus, instead of choosing the correct token, the spelling of other tricky words may have an impact on the participants' decision. For this reason, the overall scores of the perception test $(61.77 \%$ in the low proficiency group and $78.57 \%$ in the high proficiency group) were lower than the syllable identification test $(65.43 \%$ in the low proficiency group and $82.57 \%$ in the high proficiency group). As predicted, the findings of both tests should be consistent to Solt et al.'s (2004) findings. That is, the findings of both tests should be scaled as: $[\mathrm{Id}]>[\mathrm{t}]>[\mathrm{d}]$. However, the findings of syllable identification show in a different way $([\mathrm{t}]>[\mathrm{d}]>[\mathrm{Id}])$. Such inconsistent results may indicate that the participants in this study might not precisely know the rules of regular past tense pronunciation or they might be lacking in English listening practice even though they know the rules.

\subsection{Pronunciation Language Learning Strategies}

The second hypothesis (The first-year students and the third-year students use different strategies to perceive the three different allomorphs of the regular past tense morpheme /-ed/) was rejected by the questionnaire's results. The first and the third-year students do use the same strategy to perceive the three different allomorphs of the regular past tense morpheme /-ed/. The statistical findings show that there was no statistically significant difference between the two groups. Students in both groups usually listen to a song or watch any kinds of 
entertainment in English via the radio, TV or the Internet as a cognitive strategy; in addition, the first-year students also encourage themselves to work on pronunciation even when they think that something is too difficult for them or when they do not feel like learning as an affective strategy helping them perceive and produce the '-ed' ending sound. Nevertheless, the strategy that the first-year students used the least is if they do not know how to pronounce an '-ed' ending verb, they will avoid using it (compensation strategy). On the other hand, the third-year students demonstrated that the evaluating of their progress in pronunciation by recording themselves and comparing their pronunciation to the pronunciation of native speakers is the least strategy (metacognitive strategy) they employ. Other interesting strategies which both groups usually employ are metacognitive strategies and affective strategies. Their questionnaire's performances manifest that they usually notice the pronunciation when teachers or speakers speak English and compare to them in order to improve their pronunciation $(82 \%, 80 \%)$, and encourage themselves to speak English even when they are afraid that their pronunciation is not good $(80 \%, 81 \%)$.

In addition, according to the two main categories, the results which were congruent to the study's result of Rokoszewska (2012) reveal that the indirect strategies were mostly utilized among both groups $(69.34 \%$ and $68.86 \%)$. That is, in the category of direct strategies, cognitive strategies showed the highest frequency use $(72.56 \%$ and $70.84 \%)$; in other words, the use of affective strategies was the highest in the category of indirect strategies $(73.76 \%$ and $71.08 \%)$. This indicates that most students initially manage their emotions, motivation, and attitudes with English pronunciation learning along with having a conscious way to handle with the target language by practicing, receiving and sending a message, analyzing and reasoning, and creating a structure for input and output (Oxford, 1990).

\section{Conclusion}

This research was designed to investigate the extent of the perception of the English regular past tense verbs by EFL students, and to explore the use of strategies of the EFL students to perceive the three different allomorphs ([t], [d] and [Id]) of regular past tense verbs. The findings demonstrate that the language proficiency level influenced the perceptual accuracy of the regular past tense morphemes. The overall results reveal that the high proficiency group could more accurately perceive the '-ed' morphemes than the low proficiency one on both perception $(61.77 \%$ in the low proficiency group and $78.57 \%$ in the high proficiency group) and syllable identification test $(65.43 \%$ in the low proficiency group and $82.57 \%$ in the high proficiency group) (Figure 3). However, even though the results of the perception test are consistent to Solt et al.'s (2004) study the syllable identification test goes the other way. The reason why the inconsistency appeared among the results of the two tests is still unclear. Therefore, to provide more precise reasons for the inconsistency of the two tests, the qualitative data should be gathered to gain more depth information. Qualitative research instruments such as interviews and observation should be employed for further studies. Interviews can provide sufficient information via investigating the topic in an in-depth way, exploring how individuals think and feel about the topic as well as deepening understand and explaining statistical data. Moreover, observation can elicit natural in-depth information. Students' reactions or facial expressions when dealing with the three regular past tense allomorphs can paint a better and clearer picture of their understanding and performance in this topic. Furthermore, all voiced and voiceless codas were not included in the tests due to the inherent limitation of the study. Only verbs that end with codas /-p, k, f, s, $\int, \mathrm{v}, \mathrm{\partial}, \mathrm{l}, \mathrm{d} 3, \mathrm{t}, \mathrm{d} /$ and vowel sounds were chosen. Hence, future studies may consider using all voiced and voiceless codas of regular past tense verbs to thoroughly investigate the perception abilities of the EFL learners and examine the more specific language learning strategies in perceiving the '-ed' ending sounds.

This study found that there are some past tense allomorphs such as the allomorph [t] and [d] which the high proficiency group performed poorer than the low proficiency group although the high proficiency group had studied a required course "English Phonetics and Phonology". This reflects that though they know the phonological rules of regular past tense morphemes, their perceptive performance still goes against to what it should be. Therefore, the teachers should more frequently emphasize on this aspect in terms of both voiced changing rules and long-term practice. From the results of the study, the inconsistent results between the perception test and the perception syllable identification test by both groups reflect that the students lacked of practicing even though they know the rules. Thus, apart from emphasizing on the rules and the frequency of practice in class, the teachers should suggest the students to review the lessons by themselves or even practice their perception and production of regular past tense morphemes outside class. For example, the teachers can suggest useful links regarding to how to pronounce the '-ed' ending verbs from YouTube such as https://www.youtube.com/watch?v=A7hi-ipU2n0 by a native American English speaker. For the low proficiency group, the teachers can also suggest the link such as https:/www.youtube.com/watch? $\mathrm{v}=273 \mathrm{fUh} 7 \mathrm{UbbU} \& \mathrm{t}=301 \mathrm{~s}$ 
lecturing by a Thai teacher. These links offer not only the principled but also guidelines on how to pronounce the regular past tense morphemes. Besides, the teachers should raise the awareness of the students to comprehend that language learning is influenced by a long-term training and practice. The students have to frequently and continually practice their English skills since L2 learning cannot be an overnight success. It is a lifelong learning which requires time, patience, and a great deal of consistent practice.

\section{References}

Bayley, R. (1996). Competing constraints on variation in the speech of adult Chinese learners of English. Second language acquisition and linguistic variation, 97-120. https://doi.org/10.1075/sibil.10.05bay

Bayley, R. (2013). Interlanguage Variation and the Quantitative Paradigm: Past Tense Marking in Chinese-English. Research methodology in second-language acquisition (pp. 181-189). Routledge.

Birdsong, D., \& Flege, J. E. (2001, November). Regular-irregular dissociations in L2 acquisition of English morphology. In Proceedings of the 25th annual Boston University conference on language development ( $\mathrm{pp}$. 123-132). Boston, MA: Cascadilla Press.

Blom, E., \& Paradis, J. (2013). Past tense production by English second language learners with and without language impairment. Journal of Speech, Language, and Hearing Research, 56(1), 281-294. https://doi.org/10.1044/1092-4388(2012/11-0112)

Carr, P. (2012). English phonetics and phonology: An introduction. John Wiley \& Sons.

Celce-Murcia, M., Brinton, D., \& Goodwin, J. M. (1996). Teaching pronunciation: A reference for teachers of English to speakers of other languages. Cambridge: Cambridge University Press.

Declerck, R., Reed, S., \& Cappelle, B. (2006). The grammar of the English tense system: a comprehensive analysis (Vol. 1). Walter de Gruyter. https://doi.org/10.1515/9783110199888

Evans, V., \& Dooley, J. (2016). Upstream 6. Bangkok: Aksorn Charoen Tat.

Finegan, E. (2015). Language: Its Structure and Use (7th ed.). USA: Cengage Learning.

Kormos, J. (2011). Speech production and the Cognition Hypothesis. Second language task complexity: Researching the Cognition Hypothesis of language learning and performance, 39-59. https://doi.org/10.1075/tblt.2.06ch2

Kreidler, C. W. (1989). The pronunciation of English: A course book in phonology. B. Blackwell.

Lieber, R. (2009). Introducing morphology. New York: Cambridge University Press. https://doi.org/10.1017/CBO9780511808845

Lardiere, D. (2002). Second language knowledge of [ \pm past] vs. [ \pm finite]. In Proceedings of the 6th generative approaches to second language acquisition conference (GASLA 2002) (pp. 176-189). Somerville, MA: Cascadilla Proceedings Project.

Morley, J. (1991). The pronunciation component in teaching English to speakers of other languages. TESOL quarterly, 25(3), 481-520. https://doi.org/10.2307/3586981

Oxford, R. L. (1990). Language learning strategies: What every teacher should know. New York: Newbury House/Harper \& Row.

Pawlak, M. (2010). Designing and piloting a tool for the measurement of the use of pronunciation learning strategies. Research in Language, 8, 1-14. https://doi.org/10.2478/v10015-010-0005-6

Prapobaratanakul, C., \& Pongpairoj, N. (2016). Variable Production of English Past Tense Morphology: A Case Study of a Thai-Speaking Learner of English. PASAA: Journal of Language Teaching and Learning in Thailand, 51, 71-96.

Rokoszewska, K. (2012). The influence of pronunciation learning strategies on mastering English vowels. Studies in Second Language Learning and Teaching, 2(3), 391-413. https://doi.org/10.14746/ssllt.2012.2.3.7

Saville-Troike, M. (2006). Introducing second language acquisition. Cambridge, UK: Cambridge University Press.

Solt, S., Pugach, Y., Klein, E. C., Adams, K., Stoyneshka, I., \& Rose, T. (2004). L2 perception and production of the English regular past: Evidence of phonological effects. In BUCLD 28: Proceedings of the 28th Annual Boston University Conference on Language Development (pp. 553-564).

Sriphrom, S., \& Ratitamkul, T. (2014). Lexical aspect and the use of simple past tense by Thai learners of 
English. MANUSYA: Journal of Humanitites Regular, 17(1), 64-77.

Strange, W., \& Shafer, V. L. (2008). Speech perception in second language learners: The re-education of selective perception. Phonology and second language acquisition, 36, 153-192. https://doi.org/10.1075/sibil.36.09str

Szyszka, M. (2015). Good English pronunciation users and their pronunciation learning strategies. Research in Language, 13(1), 93-106. https://doi.org/10.1515/rela-2015-0017

Wolfram, W. (1985). Variability in tense marking: A case for the obvious. Language Learning, 35(2), 229-253.

Zare, P. (2012). Language learning strategies among EFL/ESL learners: A review of literature. International Journal of Humanities and Social Science, 2(5), 162-169.

\section{Appendices}

\section{Appendix A (A sample of answer sheet in the perception test)}

Direction: Listen carefully and then circle a word you hear. (35 words)

Noted: Some words may not appear in Standard English

Name:

\begin{tabular}{|c|c|c|c|}
\hline 1. A. friend & B. refrain & C. French & D. fender \\
\hline 2. A. plastic & B. passive & C. pathetic & D. passenge \\
\hline A. beach & B. beat & C. breeze & D. bidet \\
\hline A. britches & B. bride & C. brick & D. bridge \\
\hline A. compact & B. complaint & C. compass & D. complex \\
\hline A. stopped & B. stop & C. stope & D. stove \\
\hline A. rope & B. rob & C. robed & D. ropped \\
\hline A. worsed & B. worth & C. worked & D. word \\
\hline A. ran & B. ranned & C. rancid & D. rank \\
\hline 0. A. needle & B. needn't & C. needed & D. neat \\
\hline 11. A. debted & B. date & C. deft & D. depth \\
\hline 12. A. study & B. studded & C. studding & D. studied \\
\hline 13. A. leg & B. regged & C. reggae & D. recked \\
\hline 14. A. loft & B. laughed & C. loved & D. laugh \\
\hline 15. A. muched & B. mugged & C. muddle & D. mudded \\
\hline 16. A. moussed & B. mooted & C. moved & D. movie \\
\hline 17. A. taughed & B. taught & C. taugh & D. touch \\
\hline 18. A. paste & B. pass & C. part & D. passed \\
\hline 19. A. pent-up & B. paint & C. plant & D. plented \\
\hline 20. A. sound & B. sounding & C. sounded & D. saunded \\
\hline 21. A. indeeded & B. indeed & C. indeeder & D. inneed \\
\hline 22. A. raunchy & B. launch & C. runched & D. lunch \\
\hline 23. A. breeded & B. breathed & C. breached & D. beated \\
\hline 24. A. linged & B. wring & C. ring & D. lingo \\
\hline 25. A. callied & B. called & C. caller & D. call \\
\hline 26. A. gother & B. grot & C. grothe & D. grosed \\
\hline 27. A. and & B. an & C. anded & D. anted \\
\hline 28. A. in vain & B. invented & C. invent & D. inventiv \\
\hline
\end{tabular}



29. A. trush
B. trust
C. trushed
D. trashed
30. A. chanted
B. chain
C. changed
D. chanced
31. A. skumed
B. skum
C. skim
D. skump
32. A. stared
B. start
C. started
D. starter
33. A. transmit
B. transmits
C. transitted
D. transmitted
34. A. ried
B. rile
C. ride
D. rye
35. A. phoenix
B. finished
C. Phillip
D. finish

\section{Appendix B (A sample of answer sheet in the perception syllable identification test)}

Direction: Listen carefully and identify how many syllables you hear for each word. Write the number of syllables. (Perception test)

Name:

\begin{tabular}{|l|l|l|l|}
\hline No. & Number of Syllable & No. & Number of Syllable \\
\hline 1. & & 19. & \\
\hline 2. & & 20. & \\
\hline 3. & & 21. & \\
\hline 4. & & 22. & \\
\hline 5. & & 23. & \\
\hline 6. & & 24. & \\
\hline 7. & & 25. & \\
\hline 8. & & 26. & \\
\hline 9. & & 27. & \\
\hline 10. & & 28. & \\
\hline 11. & & 29. & \\
\hline 12. & & 30. & \\
\hline 13. & & 31. & \\
\hline 14. & & 32. & \\
\hline 15. & & 33. & \\
\hline 16. & & 34. & \\
\hline 17. & & 35. & \\
\hline 18. & & & \\
\hline
\end{tabular}




\section{Appendix C (A sample of questionnaire)}

The Pronunciation Learning Strategies Questionnaire (Rokoszewska, 2012)

\section{Section I General Information}

1. Sex $\square$ Male $\square$ Female

2. Age

3. Year of Education .

Major

Faculty.

4. Have you ever studied in a foreign country? (Ex. Exchange student or student of summer course)

$\square$ Yes
4.1 If yes, which country have you ever been? (If no, skip to No.5)

5. Has your family ever been a host for exchange student or foreign people? If yes, of which nationality he/she is?

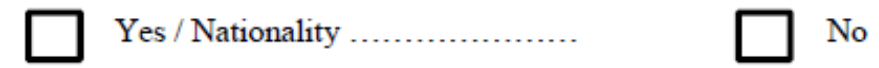

6. Do you have any foreign people to talk with in English in your daily life?
$\square$ Yes
$\square$ No

7. How many hours per week do you practice your English via any kinds of entertainment in English such as radio, TV or the Internet?

Section II Read the statements below and tick the response which indicates how often you use an English pronunciation learning strategy of according to the following scale:

\begin{tabular}{|l|l|l|l|l|l|}
\hline Ways of Learning English Pronunciation & $\mathbf{1}$ & $\mathbf{2}$ & $\mathbf{3}$ & $\mathbf{4}$ & $\mathbf{5}$ \\
never & hardly & sometimes & often & always \\
\hline Part A - Memory Strategies & & & & & \\
\hline $\begin{array}{l}\text { 1. In order to memorize the pronunciation of an "-ed" ending } \\
\text { verb I try to associate it with the pronunciation of a different } \\
\text { word (in another language I know). }\end{array}$ & & & & & \\
\hline $\begin{array}{l}\text { 2. I group words that sound similar in order to memorize the } \\
\text { pronunciation of "-ed" ending verbs. }\end{array}$ & & & & & \\
\hline $\begin{array}{l}\text { 3. In order to memorize the pronunciation of an "-ed" ending } \\
\text { verb I use phonetic symbols or my own code to write down its } \\
\text { pronunciation. }\end{array}$ & & & & & \\
\hline $\begin{array}{l}\text { 4. I memorize the pronunciation of an "-ed" ending verb by } \\
\text { visualizing its transcription. }\end{array}$ & & & & & \\
\hline $\begin{array}{l}\text { 5. I memorize the pronunciation of new words by associating } \\
\text { them with a situation in which I have heard them. }\end{array}$ & & & & & \\
\hline $\begin{array}{l}\text { 6. I record words whose pronunciation I want to memorize and } \\
\text { listen to the recording several times. }\end{array}$ & & & & & \\
\hline $\begin{array}{l}\text { 7. I review the pronunciation of recently learnt words } \\
\text { regularly. }\end{array}$ & & & & & \\
\hline Part B - Cognitive Strategies & & & & \\
\hline $\begin{array}{l}\text { 8. I repeat sounds, words, sentences, etc., after English } \\
\text { speakers to practice and remember how to pronounce each } \\
\text { word. }\end{array}$ & & & & & \\
\hline 9. I listen to a song or watch any kinds of entertainment in & & & & \\
\hline
\end{tabular}




\begin{tabular}{|c|c|c|c|c|c|}
\hline \multicolumn{6}{|l|}{ English via the radio, TV or the Internet. } \\
\hline Ways of Learning English Pronunciation & $\begin{array}{l}1 \\
\text { never }\end{array}$ & $\begin{array}{l}2 \\
\text { hardly }\end{array}$ & $\begin{array}{l}3 \\
\text { sometimes }\end{array}$ & $\begin{array}{l}4 \\
\text { often }\end{array}$ & $\begin{array}{l}5 \\
\text { always }\end{array}$ \\
\hline $\begin{array}{l}\text { 10. I observe the movements of articulators when an English } \\
\text { native speaker speaking. }\end{array}$ & & & & & \\
\hline $\begin{array}{l}\text { 11. Before I say something aloud, I practice saying a given } \\
\text { word, sentence, etc., in my mind. }\end{array}$ & & & & & \\
\hline $\begin{array}{l}\text { 12. I practice my pronunciation by speaking to myself in } \\
\text { English. }\end{array}$ & & & & & \\
\hline $\begin{array}{l}\text { 13. I look up the pronunciation of unknown words in a } \\
\text { dictionary. }\end{array}$ & & & & & \\
\hline $\begin{array}{l}\text { 14. I try to identify and use "-ed" ending verbs' pronunciation } \\
\text { rules. }\end{array}$ & & & & & \\
\hline $\begin{array}{l}\text { 15. I practice reading aloud, paying particular attention to my } \\
\text { pronunciation. }\end{array}$ & & & & & \\
\hline $\begin{array}{l}\text { 16. I analyze the differences between English pronunciation } \\
\text { and the pronunciation of other languages. }\end{array}$ & & & & & \\
\hline $\begin{array}{l}\text { 17. I listen to recordings several times in order to learn or copy } \\
\text { the pronunciation of unknown words. }\end{array}$ & & & & & \\
\hline Part C-Compensation Strategies & & & & & \\
\hline $\begin{array}{l}\text { 18. If I do not know how to pronounce an "-ed" ending verb, I } \\
\text { guess its pronunciation. }\end{array}$ & & & & & \\
\hline $\begin{array}{l}\text { 19. If I do not know how to pronounce an "-ed" ending verb, I } \\
\text { will avoid using it. }\end{array}$ & & & & & \\
\hline $\begin{array}{l}\text { 20. If I do not know how to pronounce an "-ed" ending verb, I } \\
\text { transcribe it into Thai pronunciation hoping that I will be } \\
\text { understood. }\end{array}$ & & & & & \\
\hline $\begin{array}{l}\text { 21. If I cannot produce an "-ed" ending verb, I produce a } \\
\text { sound as similar to it as possible. }\end{array}$ & & & & & \\
\hline Part D - Metacognitive Strategies & & & & & \\
\hline $\begin{array}{l}\text { 22. When I prepare a talk in English, I look up the } \\
\text { pronunciation of new words in a dictionary and practice their } \\
\text { pronunciation. }\end{array}$ & & & & & \\
\hline $\begin{array}{l}\text { 23. I notice the pronunciation when teacher or speaker } \\
\text { speaking English and compare to me in order to improve my } \\
\text { pronunciation. }\end{array}$ & & & & & \\
\hline $\begin{array}{l}\text { 24. I plan pronunciation learning - I set the time of learning, } \\
\text { select materials, strategies, etc. }\end{array}$ & & & & & \\
\hline 25. I have clear goals for improving my pronunciation. & & & & & \\
\hline $\begin{array}{l}\text { 26. I evaluate my progress in pronunciation by recording } \\
\text { myself and comparing my pronunciation to the pronunciation } \\
\text { of native speakers. }\end{array}$ & & & & & \\
\hline Part E - Affective Strategies & & & & & \\
\hline $\begin{array}{l}\text { 27. I try to relax whenever I feel afraid of reading aloud or } \\
\text { speaking in English. }\end{array}$ & & & & & \\
\hline $\begin{array}{l}\text { 28. I encourage myself to speak English even when I am afraid } \\
\text { that my pronunciation is not good. }\end{array}$ & & & & & \\
\hline
\end{tabular}




\begin{tabular}{|c|c|c|c|c|c|}
\hline $\begin{array}{l}\text { 29. I encourage myself to work on pronunciation even when I } \\
\text { think that something is too difficult for me or when I do not } \\
\text { feel like learning. }\end{array}$ & & & & & \\
\hline 30. I use a sense of humor about my mispronunciations. & & & & & \\
\hline $\begin{array}{l}\text { 31. I talk to someone else about how I feel when I am learning } \\
\text { pronunciation. }\end{array}$ & & & & & \\
\hline Part F - Social Strategies & & & & & \\
\hline $\begin{array}{l}\text { 32. I ask English speakers to correct my pronunciation when I } \\
\text { speak. }\end{array}$ & & & & & \\
\hline Ways of Learning English Pronunciation & \begin{tabular}{l|}
1 \\
never
\end{tabular} & $\begin{array}{l}2 \\
\text { hardly }\end{array}$ & $\begin{array}{l}3 \\
\text { sometimes }\end{array}$ & $\begin{array}{l}4 \\
\text { often }\end{array}$ & $\begin{array}{l}5 \\
\text { always }\end{array}$ \\
\hline $\begin{array}{l}\text { 33. I ask others for help if I do not know how to pronounce an } \\
\text { "-ed" ending verb. }\end{array}$ & & & & & \\
\hline $\begin{array}{l}\text { 34. I prefer to learn pronunciation with my friends or other } \\
\text { students. }\end{array}$ & & & & & \\
\hline 35. I help others in learning pronunciation. & & & & & \\
\hline
\end{tabular}

\section{Copyrights}

Copyright for this article is retained by the author(s), with first publication rights granted to the journal.

This is an open-access article distributed under the terms and conditions of the Creative Commons Attribution license (http://creativecommons.org/licenses/by/4.0/). 